\title{
The role of business in armed violence reduction and prevention
}

\section{Achim Wennmann*}

Dr Achim Wennmann is Researcher at the Centre on Conflict, Development and Peacebuilding (CCDP) of the Graduate Institute of International and Development Studies in Geneva.

\section{Abstract}

This article looks at business activities in violent and fragile environments through an armed violence lens and explores the role of business in armed violence reduction and prevention (AVRP) strategies. The article argues that the transformation of armed violence patterns over the last decade requires a new optic on a subject that has traditionally been discussed in the context of 'business and peace' or 'business and conflict', and of armed violence related to inter-or intra-state armed conflict. The article sets out to better understand how different constituencies have dealt with the role of the private sector in reducing armed violence, and to connect the dots between various scholarly and practice communities to identify entry points for AVRP strategies across sectors and institutions. The article suggests that such entry points exist in relation to the costing of armed violence and civic observatories.

Keywords: business, armed violence, fragility, armed violence reduction and prevention (AVRP).

Reflections about the role of the private sector in violent and fragile environments have abounded over the last decade, but so far they have not explicitly adopted an

* Special thanks go to the Secretariat of the Geneva Declaration of Armed Violence and Development (http://www.genevadeclaration.org) for the funding of this study. The Secretariat will soon be publishing a related shorter issue brief. The author also wishes to thank Vincent Bernard, Luigi de Martino, Mariya Nikolova and an anonymous reviewer for comments. 
armed violence lens. Such a lens proposes an integrated optic on modern warfare, armed conflict, and criminal violence ${ }^{1}$ with a clear operational purpose to improve strategies against armed violence in specific contexts through so-called armed violence reduction and prevention (AVRP) programmes. The debates in the field of business and peace or business and conflict have so far mainly focused on the role of companies in inter-state or civil wars, in human rights abuses, and in local peacebuilding initiatives. What is more, most recent multi-stakeholder practice has focused on the 'Protect, Respect, Remedy' framework developed in the 'Ruggie Principles', ${ }^{2}$ or on the implementation of the Voluntary Principles on Security and Human Rights. ${ }^{3}$ Thus, the current analytical and practical inventory has emerged from a more traditional conflict perspective - meaning a focus on inter-state and civil wars - and from rights approaches.

Exploring the potential of an armed violence lens for business engagements in violent and fragile contexts ${ }^{4}$ is important for a number of reasons. First, it is an operational framework for strategic, cross-sectorial collaboration that goes beyond the current dominance of rights approaches in this field. Second, it shifts the focus from the declaratory to the operational level in specific contexts. It therefore connects to an emerging trend that voluntary efforts surrounding principles and guidelines have reached a certain saturation point, and that future efforts need to be more concerned about changing practices on the ground. ${ }^{5}$ Third, the armed violence lens is much better adapted for action within the context of changing characteristics and dynamics of violent conflict. This change is exemplified by the fact that only one out of every ten reported violent deaths occurs in traditionally defined armed conflict settings. ${ }^{6}$ Finally, the lens captures a significant amount of promising practice that has so far not been related to business operations in difficult markets. This practice highlights the rise of integrated national or municipal AVRP programmes in countries such as Brazil, Colombia, and South Africa.

This article provides an exploratory analysis of the armed violence lens in relation to business operations in violent and fragile contexts. This analysis intends to raise awareness in the business and rights communities of the armed violence lens developed by the Organisation for Economic Development and Cooperation

1 Geneva Declaration Secretariat (GDS), Global Burden of Armed Violence, GDS, Geneva, 2008. Organisation for Economic Co-operation and Development (OECD), Armed Violence Reduction: Enabling Development, OECD, Paris, 2011.

2 UN Doc. A/HRC/17/31, Guiding Principles on Business and Human Rights: Implementing the United Nations 'Protect, Respect and Remedy' Framework, 21 March 2011, unanimously endorsed by the United Nations Human Rights Council on 16 June 2011.

3 Available at: http://www.voluntaryprinciples.org/files/voluntary_principles_english.pdf (last visited 14 December 2012).

4 'Violent and fragile contexts' are understood to exist where 'political, social, security and economic risks correlate with organised violence'. These occur particularly in 'periods when states or institutions lack the capacity, accountability, or legitimacy to mediate relations between citizen groups and between citizens and the state, making them vulnerable to violence'. See World Bank, World Development Report 2011: Conflict Security and Development, World Bank, Washington, D.C., 2011, pp. xv-xvi.

5 Brian Ganson and Achim Wennmann, Confronting Risk, Mobilizing Action: A Framework for Conflict Prevention in the Context of Large-scale Business Investments, Friedrich Ebert Stiftung, Berlin, 2012.

6 GDS, Global Burden of Armed Violence: Lethal Encounters, Cambridge University Press, Cambridge, 2011, p. 1 . 
(OECD) and the Geneva Declaration on Armed Violence and Development. It also highlights the potential this lens has to serve as a strategic tool to operationalize cross-sectorial collaboration in violent contexts. The paper understands 'business' to mean private companies - local or international - that are involved in the financing, production, or trade of legal or legitimate goods and services. It does not focus on private actors associated with organized crime, although it acknowledges that the distinction between formal and informal, public and private, or legal and illegal can be blurred in many violent and fragile contexts. The article also does not focus on private security firms whose business is the provision of security services. Armed violence is understood as 'the intentional use of force (actual or threatened) with arms or explosives, against a person, group, community, or state that undermines people-centered security and/or sustainable development'. 7 This working definition covers armed violence perpetrated in both armed conflict and non-conflict settings.

The analysis proceeds in five parts. The first part describes the main elements of the armed violence lens. The second part reviews the existing state of knowledge about business and armed violence. The third part tracks different forms of business engagements around, in, or on armed violence. The fourth part places selected business practice within the scope of the armed violence lens. The fifth part explores two convergence points for cross-sectorial collaboration in support of AVRP programmes. Overall, the article acknowledges the multitude of roles that business has played across various violent contexts. It also highlights that the role of business in AVRP programmes is not necessarily about the mapping or enhancement of stand-alone corporate projects to reduce armed violence, but about the place of business within comprehensive strategies in specific contexts.

\section{The armed violence lens}

The armed violence lens results from a multi-year process of the OECD and the Geneva Declaration. It was developed in consultation with development practitioners and grounded in over a decade of practice on armed violence reduction in conflict, post-conflict, and other violence-affected contexts. This process was built on the recognition that armed violence impedes the achievement of the Millennium Development Goals (MDGs), and on the assumption that measurable reductions in armed violence can lead to significant development gains.

The armed violence lens proposes a strategically integrated approach to combat armed violence. This approach rests on the premise that 'the promotion of effective and practical measures to prevent and reduce armed violence depends on the development of reliable information and analysis of its causes and consequences, and its interrelationships at numerous levels' ${ }^{8}$ Overall, the armed violence lens cuts

8 OECD, Armed Violence Reduction, above note 1, p. 49. 


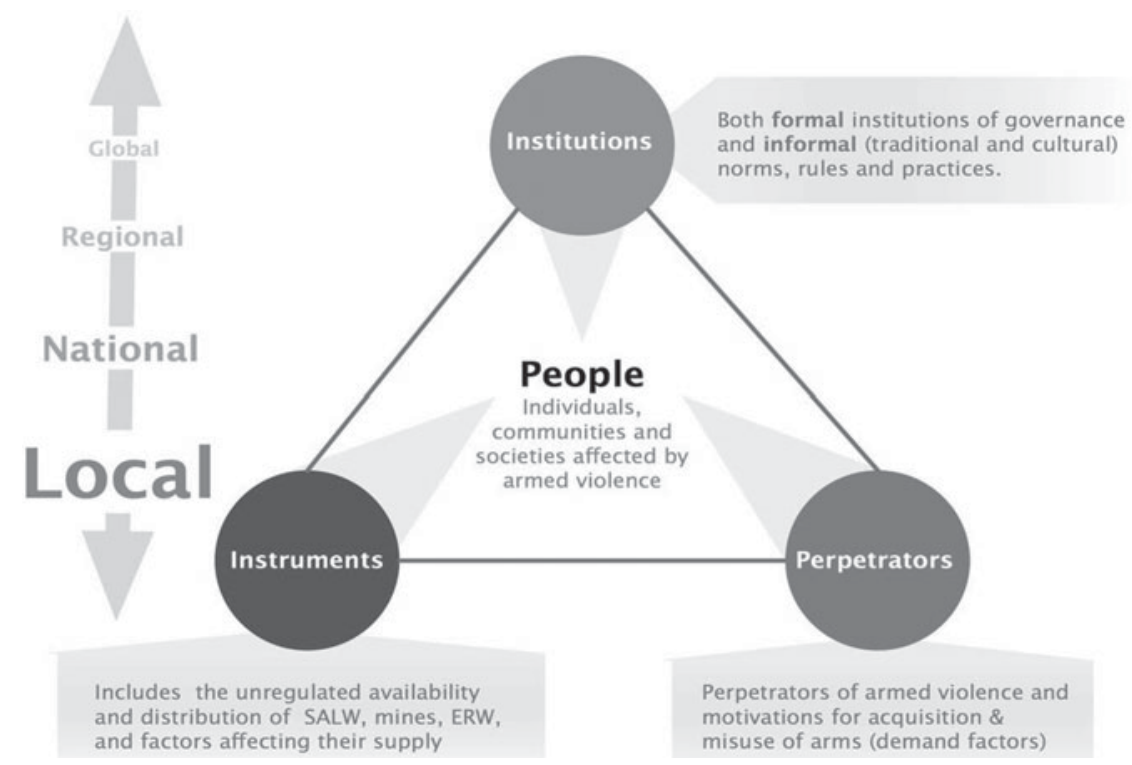

Figure 1. The armed violence lens. (C) OECD. Armed Violence Reduction: Enabling Development, 2011, p. $50 .^{10}$

across local, national, regional, and global levels and rests on four elements (see Figure 1). These elements are:

- the people and communities affected by armed violence;

- the perpetrators of armed violence and their motives to use armed violence;

- the instruments of armed violence, including small arms and light weapons; and

- the formal and informal institutions that define the wider environment that enables, or protects against, armed violence. ${ }^{9}$

The armed violence lens 'underscores the way violence transcends separate development sectors, and highlights the potential for cross-sector and integrated responses'. ${ }^{11}$ The lens also recognizes the multiple faces of armed violence, including the 'simultaneous, and shifting motivations of violent actors, and the links between different forms of violence' including organized (collective) or interpersonal (individual) violence, and conflict (politically motivated) and criminal (economically motivated) violence. ${ }^{12}$

The framework also spells out a series of risk factors associated with armed violence at the individual, relationship, community, and societal levels - a conceptualization also known as the ecological model of armed violence. ${ }^{13}$ At the

$9 \quad$ Ibid., pp. 49-50.

10 'SALW' refers to 'small arms and light weapons'; 'ERW' refers to 'explosive remnants of war'.

11 Ibid.

12 GDS, above note 1, p. 18.

13 World Health Organization (WHO), World Report on Violence and Health, WHO, Geneva, 2002, pp. 12-15. 
individual level violence is often related to youth, males, poor behaviour control, history of aggressive behaviour, low educational achievement, substance abuse, or previous exposure to violence. At the relationship level, violence has been found to be rooted in poor family supervision, exposure to punishment, low family attachment, low socio-economic status, or association with delinquents. At the community level, low social capital, high levels of unemployment, gangs, guns, and narcotics, and access to alcohol has been related to violence. And at the societal level, quality of governance, laws on social protection, income inequality, urban growth, and cultures sanctioning violence are critical factors.

AVRP programmes exhibit a tremendous diversity, dynamism, entrepreneurship, and social innovation. At the same time, they share a number of common features. These include:

- creative adaptation of conflict, crime, and armed violence prevention approaches to specific contexts;

- a focus on the local level because this is where armed violence is experienced most directly, and where evidence suggests the most promising efforts have occurred;

- a focus on the mitigation of regional and global risk factors that impact on local dynamics; and

- national level efforts that help ensure the sustainability of local prevention efforts, in particular, ensuring learning across local settings, developing a vision of AVRP across different institutions and sectors, and helping prioritization and coordination. ${ }^{14}$

One review of promising practice highlights that:

The most promising AVRP programmes are those that bring together a range of violence prevention and reduction strategies across a number of sectors and purposefully target the key risk factors that give rise to armed violence ... [and that] integrate AVRP objectives and actions into regional, national, and sub-national development plans and programmes. ${ }^{15}$

AVRP programmes are frequently distinguished along three lines. Direct programmes address the instruments, actors, and institutional environments enabling armed violence; indirect programmes address 'proximate' and 'structural' risk factors giving rise to armed violence; and broader development programming, while not having prevention and reduction of armed violence as a primary or even secondary objective, can nevertheless generate meaningful dividends. These three categories are not necessarily mutually exclusive or pursued in isolation of one another. Indeed, many cutting-edge AVRP programmes intentionally blur direct and indirect approaches - for example, focusing simultaneously on reducing firearms availability and working with at-risk male youth while seeking to mitigate the

14 OECD, above note 1, p. 17.

15 Paul Eavis, Working Against Violence: Promising Practices in Armed Violence Reduction and Prevention, GDS, Geneva, 2011, pp. 57-58. 
likelihood of misuse through targeted employment schemes, after-school education programmes, psychological support, and even family-planning activities. ${ }^{16}$

From the perspective of local businesses - large and small - direct engagement in efforts to combat armed violence is certainly nothing new. In fact, experience from Latin America suggests that business already takes part in AVRP programmes. ${ }^{17}$ What is more, in peacebuilding practice, local actors have a long record of working with business to end violence, and consolidate peace. ${ }^{18}$ However, what may be new is that the armed violence lens - and the associated practice from AVRP programmes - opens opportunities to strengthen multi-sector partnerships necessary to combat and prevent armed violence - an effort that no actor could claim to be able to effectively do on its own.

The following section starts unpacking the link between business and armed violence in general; further below in the article a reconnection with armed violence will be made.

\section{Business and armed violence}

The concept of armed violence has so far not featured explicitly in the large literature on business engagements in violent and fragile contexts. Over the last two decades this literature has focused on a series of overlapping themes which include, for instance, the role of, and policy response to, business in inter-state and civil wars; the complicity of business in human rights abuses in conflict zones; regulatory frameworks, multi-stakeholder initiatives, and business self-regulation in situations of armed conflict and fragility; private-sector role in peacebuilding; the role of business in peace mediation; corporate-community relations; and private-sector development in post-conflict countries. ${ }^{19}$

Contributions on these themes represent a huge variety of perspectives and case studies with regard to the role of business in armed conflict situations and in peacebuilding processes. These contributions also added to policy initiatives such as the Kimberley Certification Scheme against conflict diamonds, the Extractive Industries Transparency Initiatives, as well as the Ruggie and Voluntary Principles mentioned above. This discussion and practice has been closely associated with the characteristics of some armed conflicts in the early 2000s (Angola, Democratic Republic of the Congo, Liberia, Sierra Leone) that exposed the link between state and non-state armed actors and natural resource exploitation and the integration of armed conflict areas into the global economy. ${ }^{20}$ This literature and practice mainly

16 Ibid., pp. 22-23.

17 P. Eavis, above note 15, pp. 9, 57.

18 Jessica Banfield, Canan Gündüz and Nick Killick (eds), Local Business, Local Peace: The Peacebuilding Potential of the Domestic Private Sector, International Alert, London, 2006.

19 For a review, see Mary Porter Peschka, The Role of the Private Sector in Fragile and Conflict-Affected States, World Bank, Washington, D.C., 2011.

20 See for instance, Mats Berdal and David M. Malone (eds), Greed and Grievance: Economic Agendas in Civil Wars, Lynne Rienner, Boulder, 2000; Karen Ballentine and Jake Sherman (eds), The Political Economy of Armed Conflict: Beyond Greed and Grievance, Lynne Rienner, Boulder, 2003. 
employed analysis related to inter-state and civil war, and approached the issue mainly from a compliance, self-regulation, peacebuilding, or human rights perspective, with little attention to the linkages between these different perspectives or the possibility of integrating them into a more holistic approach.

A more directed focus on armed violence and business has been developed in crime prevention. ${ }^{21}$ This particular literature highlights that 'violent crime and the perception of crime can affect a company's ability to attract customers, recruit and retain employees, boost workplace morale and ensure the productivity of its employees, and in some cases, to stay in business' ${ }^{22}$ Research focusing on crime against business (burglary, shoplifting, theft, fraud) finds that commercial premises face greater risk of victimization than private residences. ${ }^{23}$ However, the literature remains weak on the impact of crime on the development and survival of urban business. ${ }^{24}$ Recent efforts have especially focused on expanding the evidence base with regard to public-private partnerships to strengthen community safety as part of broader national crime prevention strategies. ${ }^{25}$

Given this state of the field study and practice, it is timely to ask: What do we know about the relationship between business and armed violence?

\section{Business and foreign direct investment}

First of all, we know that many types of businesses operate in violent contexts. As a proxy for the presence and interests of international companies in violent contexts, Table 1 shows the levels of foreign direct investment (FDI) and remittances in countries with high levels of armed violence. These figures illustrate that high violence contexts are not beyond the reach of private financial flows, be that flows for corporate investments in terms of FDI, or flows from private individual in terms of remittances. ${ }^{26}$ This is not to say that these flows would increase if violent levels were reduced; it means that investment occurs despite the presence of armed violence. One aspect to note is that the figures of Table 1 are indicators of violence at the national level and may hide important differences between regions or cities within a country. At the sub-national level these figures can mean a spatial overlap of high levels of violence and the concentration of business presence, as exemplified by Johannesburg or São Paolo, which are the respective business hubs of South Africa and Brazil and high violence contexts.

21 For a review, see Laura Capobianco, Sharpening the Lens: Private Sector Involvement in Crime Prevention, International Centre for the Prevention of Crime, Montreal, 2005, pp. 13-14.

22 Ibid., p. 13.

23 Jan J. M. van Dijk and Gert J. Terlouw, 'An international perspective of the business community as victims of fraud and crime', in Security Journal, Vol. 7, 1996, pp. 157-167.

24 L. Capobianco, above note 21, p. 13.

25 International Centre for the Prevention of Crime (ICPC), the World Bank, Bogota Chamber of Commerce (BCC), and Instituto Sou da Paz (ISP), Public-Private Partnerships and Community Safety: Guide to Action, ICPC, World Bank, BCC, ISP, Montreal, Washington, D.C., Bogota, São Paolo, 2011.

26 FDI and remittance flows are very different in nature, with the former having a significant concentration in the extractive and infrastructure sectors, and the latter capturing money sent by workers or the diaspora directly to family members in the home country. Remittances can increase the resilience of households and can also represent investments in micro or small family enterprises. 
$\underset{\Im}{\mathscr{N}}$ Table 1. FDI and remittances flows in countries with high levels of armed violence, annual averages 2004-200927

\begin{tabular}{|c|c|c|c|}
\hline & Violent death rate by 100,000 population & FDI (US\$ million) & Remittances (US\$ million) \\
\hline El Salvador & 61.86 & 191 & 3,326 \\
\hline Iraq & 59.40 & 913 & 249 \\
\hline Jamaica & 58.10 & 835 & 1,932 \\
\hline Honduras & 48.60 & 699 & 2,231 \\
\hline Colombia & 45.77 & 7,788 & 4,009 \\
\hline Venezuela, RB & 44.64 & 671 & 146 \\
\hline Guatemala & 43.20 & 583 & 3,685 \\
\hline South Africa & 38.39 & 4,629 & 746 \\
\hline Sri Lanka & 37.09 & 457 & 2,434 \\
\hline Lesotho & 33.67 & 83 & 610 \\
\hline Central African Republic & 32.95 & 52 & $\mathrm{n} / \mathrm{a}$ \\
\hline Sudan & 32.30 & 2,366 & 1,767 \\
\hline Belize & 31.34 & 128 & 63 \\
\hline Congo, Dem. Rep. & 31.29 & 973 & $\mathrm{n} / \mathrm{a}$ \\
\hline Swaziland & 26.47 & 59 & 93 \\
\hline Congo, Republic of the & 26.10 & 1,157 & 14 \\
\hline Somalia & 26.03 & 75 & $\mathrm{n} / \mathrm{a}$ \\
\hline Brazil & 25.85 & 26,268 & 4,179 \\
\hline Malawi & 25.47 & 94 & $\mathrm{n} / \mathrm{a}$ \\
\hline
\end{tabular}


The continuation of international business investments in many violent countries supports the proposition that armed violence is just one of a whole series of factors that define business decisions. These factors can include the quality of national legal frameworks, the banking sector, and the justice system, as well as the compatibility between the commercial objectives of the investor and the geography or geology of a country and the skill profile of its workforce. For mainstream investment projects it is therefore not necessarily the end of the conflict or the reduction of armed violence, but rather the construction of a functioning state and other location specific factors that define a willingness to invest. ${ }^{28}$ The latter point underlines how important the overall political and legislative environment is for business investments.

\section{Attitudes and perceptions of business towards armed violence}

The analysis surrounding Table 1 is corroborated by a 2006 survey of 177 executives about attitudes to risk in emerging economies. The study confirms the increasing corporate efforts to address political and operational risk management. Two thirds of respondents confirmed having increased such efforts in the period 2004-2006. The top five risks identified as 'very significant' and 'significant' were associated with political regime stability, economic problems in the host country, bribery and corruption, abrupt change in policies or ruling party, and the failure to honour contracts. War and social unrest ranked seventh out of eleven risk factors. The survey did not include armed violence as a specific risk factor category. ${ }^{29}$ Given the diversity of business, attitudes to armed violence can be very different. As regards investment in conflict countries, company attitudes have been found to depend on four principle factors:

- the magnitude of physical assets in specific violence-affected areas (for example, large-scale site-specific investments in non-movable assets such as roads, buildings, production chains);

- the core business of the enterprise (for example, natural resource exploitation, services, construction, or transportation);

- the strategy behind the investment (for example, outputs that are produced for foreign or domestic markets, or the use of integrated production cycles); and

- the level of exit costs (defined as the balance between fixed and mobile assets).

Variations of these characteristics define the costly consequences of armed violence for the company, which in turn can shape company attitudes towards dealing with such violence. According to this analysis, investments in energy and natural

27 Figures for armed violence based on data from the Geneva Declaration Secretariat. The table includes the nineteen most violent countries measured by the violent death rate per 100,000 population. GDS, above note 1, p. 53. Figures for FDI and remittances are based on World Bank Data (http://data.worldbank.org) for the annual averages in the period 2004-2009 for the indicators 'Foreign direct investment, net inflows (BoP, current US\$)' and 'Workers' remittances and compensation of employees, received (current US\$)'.

28 Ashraf Ghani and Claire Lockhart, Fixing Failed States: A Framework for Rebuilding a Fractured World, Oxford University Press, Oxford, 2008, p. 133. John Bray, Foreign Direct Investment in Conflict-Affected Contexts, International Alert, London, 2010, p. 2.

29 Economist Intelligence Unit (EIU), Operating Risks in Emerging Markets, EIU, London, 2006, pp. 2, 3, 5. 
resources, for example, tend to be more vulnerable to armed violence, while investments in financial, education, professional services, telecommunication, or construction tend to be less vulnerable. ${ }^{30}$

This differentiation of the impact of armed violence is also confirmed in the literature on the impact of violent crime on business. Sectors particularly affected are tourism, retail, transport, distribution, and storage businesses. ${ }^{31}$ What is more, increasing levels of armed violence had significant consequences for service delivery in low-income neighbourhoods of large US cities. ${ }^{32}$

The risk perception of business depends to a large extent on the subnational distribution of armed violence. If a company has its main activity in the capital but most armed violence takes place in remote areas, such violence has little effect on business operations. Thus, the measurement of FDI and armed violence as a national aggregate explains why some countries can maintain relatively high levels of FDI despite high levels of armed violence.

\section{Business engagement around, in, or on armed violence}

Given the presence of some companies in violent and fragile settings, the question is then how do they adjust their presence or operations to armed violence? Overall, companies have the options to adjust their operations to work around, in, or, on armed violence. ${ }^{33}$

\section{Companies working around armed violence}

Most mainstream companies work around armed violence, which means that as a result of armed violence they withdraw or temporarily cease activities. Companies adjusting operations in this way, therefore, do not see a benefit to engaging in the reduction of armed violence directly. However, companies can be extremely hesitant to withdraw. As they operate in a competitive market their withdrawal represents an opportunity for a competitor to enter the market. This potential substitutability of commercial actors highlights the importance for companies with a generally reputable record in conflict and fragile settings to stay on because the alternative would be opening the door to profit-makers that purposefully deviate from responsible practice. ${ }^{34}$ Another argument can be made regarding the temporary closure of

30 Andreea Mihalache-O'Keef and Tatiana Vashchilko, 'Foreign direct investors in conflict zones', in Mats Berdal and Achim Wennmann (eds), Ending Wars, Consolidating Peace: Economic Perspectives, Routledge for IISS, Abingdon, 2010, pp. 137-155.

31 L. Capobianco, above note 21, p. 15.

32 This finding is based on research using longitudinal data on business behaviour in five large US cities between 1987 and 1994. Robert Greenbaum and George Tita, 'The impact of violence surges on neighbourhood business activity', in Urban Studies, Vol. 41, No. 13, 2004, pp. 2495-2514.

33 This analysis draws on the options for development actors in conflict-sensitive development engagement. See Jonathan Goodhand, Violent Conflict, Poverty and Chronic Poverty, Chronic Poverty Research Centre Working Paper No. 6, University of Manchester, Manchester, 2001, pp. 30-31.

34 John Bray, 'Attracting reputable companies to risky environments: petroleum and mining companies', in Ian Bannon and Paul Collier (eds), Natural Resources and Violent Conflict: Options and Actions, World Bank, Washington, D.C., 2003, p. 309. 
business: while bigger companies may have the resources to withstand prolonged episodes of closure, prolonged disruption of production or trading can place the survival of small-to-medium-sized companies at risk.

\section{Companies working in armed violence}

Companies can also decide to work in situations of armed violence and attempt to minimize the effect of armed violence on their operations and activities. For bigger companies this means paying for protection from private security companies, which can be a substantial cost factor in some contexts. Oil firms in Algeria, for example, have been estimated to devote 9 per cent of their operations budget to security. ${ }^{35}$ Small and medium-sized enterprises (SMEs) are unable to afford protection or spread risks in the same way as large investors. Crime victimization surveys in Jamaica have shown that smaller companies pay a higher share of their revenues (17 per cent) for security in comparison to a medium-sized (7.6 per cent), and large companies $\left(0.7\right.$ per cent). ${ }^{36}$ Furthermore, studies from the United Kingdom and Australia have highlighted that small retail businesses are the most vulnerable to victimization, including in terms of the financial and psychological costs of crime. ${ }^{37}$ Working in armed violence is therefore much more problematic for smaller enterprises than for bigger ones.

\section{Companies working on the drivers of armed violence}

Business can also work on the drivers of armed violence, which means that it can take various roles in AVRP. As a businessman from Colombia put it: 'It is not true that we all sit with our arms crossed, that nothing is being done, or that everyone is living in Miami'. ${ }^{38}$ Case evidence from the literature on business and peacebuilding also shows that business can work on the drivers of armed violence by building bridges between different communities and between state and society, engaging directly in talks with belligerents, providing good offices and information, acting as a pro-peace constituency, paying for (part of) a peace process, assisting in the delivery of humanitarian aid, strengthening local economies, building trust, fostering accountability, and limiting access to conflict financing. ${ }^{39}$ Business representatives

35 Peter W. Singer, Corporate Warriors: The Rise of the Privatized Military Industry, Cornell University Press, Ithaca, 2003, pp. 81-82.

36 United Nations Office on Drugs and Crime (UNODC) and the World Bank, Crime, Violence, and Development: Trends, Costs and Policy Options in the Caribbean, UNODC and World Bank, Vienna and Washington, D.C., 2007, pp. 48-49.

37 British Chamber of Commerce (BCC), Setting Business Free from Crime: A Crime Against Business, BCC, London, 2004. Santina Perron, Crime Against Small Business in Australia: A Preliminary Analysis, Australian Institute of Criminology, Canberra, 2000.

38 Angelika Rettberg, Business-Led Peacebuilding in Colombia: Fad or Future of Country in Crisis?, Crisis States Programme Working Paper 58, London School of Economics, London, 2004, p. 21.

39 For a diverse set of case studies on business engagement in peacebuilding see J. Banfield et al., above note 18; Jane Nelson, The Business of Peace: The Private Sector as a Partner in Conflict Prevention and Resolution, The Prince of Wales Business Leaders Forum, International Alert, Council on Economic 
can also act as facilitators between conflicting parties if they are perceived as apolitical and have no stakes in the outcomes of the negotiations. ${ }^{40}$

\section{The case for SMEs and large-scale investors in AVRP}

Within the strategies to adjust around, in and on armed violence, there are two types of corporate actors with a particular potential interest in engaging in AVRP. The first are local small-to-medium-sized enterprises (SMEs) because they cannot isolate themselves from armed violence on their own and therefore rely on a broader effort to end violence in order to maintain business activities. There may be a particular opportunity to strengthen community-level AVRP because SMEs use bonds between family and community members as a basis of trust to kick-start commercial transactions. In this way they strengthen community bonds and improve livelihoods, and thereby directly impact on the people's experience of life after violence.

The extractive industries, agribusiness, and infrastructure companies are the second type of commercial actor. These business types are dependent on the specific locational factors (presence of natural resources, location of agricultural land, buildings, roads, airports, etc.). As a result, they can find themselves trapped in situations of armed violence in a specific location because the level of investment is too high to allow them to withdraw. Company approaches to managing 'trapped' investments have so far tended to focus on securitized responses: for example, the hiring of a security company to fend off violent attacks against specific sites. Yet these security providers can quickly become themselves part of the armed violence dynamics. With the pressures to cut cost on security expenses, the negative publicity associated with such practices, and the limited long-term impact on reducing the risk to violent attacks against specific sites, some large-scale investors have turned increasingly to non-securitized responses. These include, for instance, informal mediation and engagement models with armed groups, and efforts towards comprehensive agreements between the company and the community. This emergent practice may demonstrate that there is a sub-group of commercial actors that could have a potential interest and ability to engage in AVRP.

Overall, SMEs, as well as large-scale investors, emphasize the potential resilience of entrepreneurs in the face of armed violence.

\section{Business practice and the armed violence lens}

Viewing business practice through the armed violence lens illustrates how such practices relates to two of the four elements of the lens: people and communities affected by armed violence and the perpetrators of armed violence. Companies, for

Priorities, London and New York, 2001, pp. 73-140; Derek Sweetman, Business, Conflict Resolution and Peacebuilding, Routledge, Abingdon, 2009, pp. 41-47.

40 Salil Tripathi and Canan Gündüz, A Role for the Private Sector in Peace Processes? Examples and Implications for Third-Party Mediation, Centre for Humanitarian Dialogue, Geneva, 2008, p. 25. 
instance, can become directly engaged in reducing armed violence if their operations or staff are at risk. In Colombia, the fact that chief executive officers (CEOs) have been kidnapped is said to have contributed to the involvement of business leaders in crime control and violence reduction initiatives. ${ }^{41}$ What is more, the perception of armed violence as a risk to the bottom line or the survival of an investment project can motivate business to act swiftly. Escalating levels of violence in Nigeria have made the engagement of armed groups a short-term priority for companies in order to protect investment assets. ${ }^{42}$

More broadly, the motivation for business to engage in armed violence reduction depends to a large extent on how boards or CEOs perceive the role of the company in relation to the state and society. Some work on the assumption that business is purely profit-driven with the profit being the company's end goal. However, there are leaders who stress that in a forward-looking company profits are a means to achieve commercial objectives and not an end in itself. These objectives are to supply goods and services that customers need or want, and these goods and services have to be constantly innovated in order to stay competitive. ${ }^{43}$ Yet there are some business leaders who clearly understand that business is as much about business as it is about politics. This is especially the case when company operations are of strategic significance to a host country or when political and business elites are intricately interwoven - even to a point where it makes little sense to separate the public and private sectors.

Another attitude is linked to the long-term sustainability need of business and the consequent need for a stable operating environment. The example of the achievement of a truce between two major gangs in El Salvador illustrates this point. While the truce between the Salvatrucha and 18th Street gangs has led a 32 to 40 per cent reduction of murder rates, there has been relatively little change in the level of extortion attempts against families and SMEs. This is because extortion remains the principal source of income of gang members and the means to pay the legal fees to support imprisoned family members. Business, therefore, would have an interest in a more integrated AVRP strategy that not only reduces the number of killings, but also addresses the economic and social dimension of armed violence though a long-term process. ${ }^{44}$

For illustrative purposes, the next two sections will look at business practice through the armed violence lens. We will focus on the same two of the four elements: the people and communities affected by armed violence and the perpetrators of armed violence. In general, efforts that directly target the instruments of armed violence as part of a strategy to reduce violence against the company or employees

41 A. Rettberg, above note 38.

42 Personal communication with the author.

43 Mark Moody-Steward, 'Foreword', in Oliver F. Williams, C.S.C. (ed.), Peace Through Commerce: Responsible Corporate Citizenship and The Ideals of the United Nations Global Compact, University of Notre Dame Press, Notre Dame, 2008, p. xi.

44 Randal C. Archibold, “'Gangs” truce buys El Salvador a tenuous peace', in The New York Times, 27 August 2012. Committee in Solidarity with the People of El Salvador, 'Salvadoran government accused of negotiating with gangs, after 40\% drop in murders', 20 April 2012, available at: http://www.cispes.org (last visited 24 August 2012). 
are less common. As was noted above, however, some companies have made efforts to not mobilize instruments of armed violence and respond to violence or threats of violence though non-securitized means. Furthermore, business practice is very diverse and there would certainly be room for a more systematic analysis of a broader sample of company strategies and their place in the armed violence lens.

\section{People and communities affected by armed violence}

There is a tremendous track record of business practice with regard to companycommunity relationships. ${ }^{45}$ Traditionally, such efforts have been associated with philanthropic investment, which is still used as a tool to structure companycommunity relations, and are usually part of a company's corporate social responsibility (CSR) engagement. In relation to crime and violence prevention projects in seven Latin American countries, one study finds that cash donations remain the most common form of business engagement. Out of forty-six projects, forty-five received private-sector donations, while many companies also became directly involved in the implementation of the project for which they provided major funding. Most projects are locally based AVRP programmes, so they focus on the immediate environment of the company. ${ }^{46}$

Beyond such philanthropic efforts, companies have been involved in multiple other ways to strengthen community capacities. ${ }^{47}$ These include, for instance: the sharing of managerial and technical expertise and skills as communities design public safety plans or other AVRP engagement; the provision of office space for neighbourhood meetings; the sponsoring of neighbourhood events to strengthen community cohesion, and the design of company policies to ensure diversity at the workplace and wider social integration objectives. In South Africa and Brazil efforts of these types have accompanied existing AVRP programmes of state, municipal or civil society actors. ${ }^{48}$

Such community-level AVRP could easily be connected to trends in the corporate world to ensure a stable operating environment. ${ }^{49}$ At least at the level of corporate policy most global companies active in fragile environments acknowledge that it is in their best interest to manage their own operations in ways that help prevent conflict and armed violence. Early investments in conflict prevention are increasingly seen as a wise long-term corporate strategy when companies decide to heavily invest in a specific location. Such a strategy in turn has the potential to

45 Luc Zandfliet and Mary B. Anderson, Getting It Right: Making Corporate-Community Relations Work, Greenleaf Publishing, Sheffield, 2009. David Brereton, John Owen and Julie Kim, Good Practice Note: Community Development Agreements, Centre for Social Responsibility in Mining, University of Queensland, Brisbane, 2011.

46 ICPC et al., above note 25, p. 33.

47 For a case study on South Africa, see Lloyd Vogelman, Reducing Violence in South Africa: The Contribution Business Can Make, Centre for the Study of Violence and Reconciliation, Pretoria, 1990.

48 L. Capobianco, above note 21, p. 20.

49 Brian Ganson and Achim Wennmann, Safe Communities, Resilient Systems: Towards a New Action Framework on Business and Peacebuilding, Brief No. 5, Geneva Peacebuilding Platform, Geneva, 2012. 
positively impact on a company's balance sheet by reducing risks related to operational disruptions, damage to property, or injury to people..$^{50}$

Among experts within companies, this trend is evidenced by an emerging mindset shift from safe operations to safe communities. Beyond the focus on the safety of people, assets, and operations directly linked to the company and its operations, the concept of safe communities refers to broader investments in community capacities to respond to conflict and risk factors from whatever source, protecting both company and community interests in broader peace and stability. ${ }^{51}$ As part of these efforts, some companies position themselves as members of the community, developing their capacity to work collaboratively with both public officials and the communities impacted by their operations. In the context of investments in New Caledonia, for instance, the Brazilian mining company Vale engaged in an inclusive effort with the Kanak people that led to a sustainable development pact which included provisions for education, training, and cultural activities, as well as the establishment of a multiparty committee on which local tribes are represented and which mointors environme the environmental aspects of Vale's operations. ${ }^{52}$

Extensive case analysis confirms that a safe place for dialogue and dispute resolution is important for both companies and communities..$^{53}$ There is also an emerging practice of placing consent and grievance processes within the community rather than within the company, and an increased sharing of decision-making control with other stakeholders. ${ }^{54}$

This practice illustrates that many private companies may have engaged in AVRP practices for years even though they did not call it AVRP. A similar finding emerged from a global assessment of AVRP programmes and which highlighted that many development programmes involved conflict prevention, peacebuilding, or security and safety priorities even though they were not described as AVRP interventions. ${ }^{55}$

\section{Perpetrators of armed violence}

While directly engaging with rebel groups, youth gangs, or military factions is a less common practice of companies, there are examples of company representatives - or

50 Brian Ganson, Business and Conflict Prevention, Towards a Framework for Action, Paper No. 2, Geneva Peacebuilding Platform, Geneva, 2011

51 Brian Ganson and Achim Wennmann, Operationalizing Conflict Prevention as Strong, Resilient Systems, Approaches, Evidence, Action Points, Paper 3, Geneva Peacebuilding Platform, Geneva, 2012.

52 Rafael Benke, Vale New Caledonia: Negotiating a Sustainable Development Pact with Local Stakeholders, 2010, available at: http://baseswiki.org/en/Vale_New_Caledonia,_Negotiation_of_a_Sustainable_ Development_Pact_with_Local_Stakeholders,_Canada_2008 (last visited 24 May 2012).

53 Compliance Advisor Ombudsman (CAO), Annual Report 2010 and Review FY 2000-10, CAO, Washington, D.C., 2010.

54 Lisa J. Laplante and Suzanna A. Spears, 'Out of the conflict zone: the case for community consent processes in the extractive sector', in Yale Human Rights and Development Law Journal, Vol. 1, 2008, p. 115.

55 Robert Muggah and Achim Wennmann (eds), Investing in Security: A Global Assessment of Armed Violence Reduction Initiatives, OECD, Paris, 2012, p. 13. 
their intermediaries - engaging perpetrators of violence. Such engagement, however, is very poorly documented. Talks occur away from the public eye, especially in the context where gangs or rebel groups pressure companies for protection payments or war taxes. For instance, local business in Sri Lanka and Nepal succumbed to the pressures by making deals with Liberation Tigers of Tamil Eelam (LTTE) and the Communist Party of Nepal-Maoist, respectively, and paying war taxes in order to stay in business and reduce the risk of threats of violence against their staff and operations. ${ }^{56}$

A prominent case in a civil war setting was in Mozambique where the British multinational company Lonrho became involved in the peace negotiations after attacks on its installations in 1990. Previously, it had paid off belligerents to protect its $£ 53$ million investments, but as the conflict escalated it was no longer immune to attacks. One of the company's executives, Roland 'Tiny' Rowland, acted as an intermediary and made available company resources and aircraft to facilitate the peace process. The company is also said to have contributed between US\$6 and 8 million to assist in the transformation of the Resistência Nacional Moçambicana (RENAMO) into a political party. ${ }^{57}$

Even though such efforts are not necessarily their core business, companies have played numerous roles in peace processes over the last two decades. They have facilitated communication and provided strategic information on issues such as prospective resource deposits and future economic potential. Using their networks and skills, companies have acted as direct intermediaries and have provided financial resources to pay for peace processes. ${ }^{58}$ Given that much of this work remains discreet, it is difficult to discuss it beyond citing anecdotal evidence.

In addition to such sensitive engagements, companies have engaged with perpetrators, regarding, in particular, the issue of reintegration of offenders and former combatants. Finding jobs for thousands of former combatants or criminal offenders is a known challenge for post-conflict and violent settings. Criminologists have shown that ex-offenders who gain and maintain employment are much less likely to reoffend than those remaining unemployed. ${ }^{59}$ Fostering the creation of private-sector jobs has therefore become an important interest of governments as a means to drive reconciliation strategies and to get at-risk youth populations off the streets.

Companies have, however, expressed certain reservations. These have included, for instance, fears of bad publicity and upsetting staff relations, or concerns regarding the suitability and skill-set of ex-offenders or ex-combatants for

56 Ameed Dhakal and Jhalak Subedi, 'The Nepalese private sector: waking up to conflict', in J. Banfield et al., above note 18, pp. 411-412. D. Rajasingham-Senanayake, 'The dangers of devolution: the hidden economies of armed conflict', in Robert I. Rotberg (ed.), Creating Peace in Sri Lanka: Civil War and Reconciliation, Brookings Institution Press, Washington, D.C., 1999, p. 61.

57 A. Vines, 'The business of peace: “Tiny" Rowland, financial incentives, and the Mozambican settlement', in J. Armon, D. Hendrickson and A. Vines (eds), The Mozambican Peace Process in Perspective, Conciliation Resources, London, 1998.

58 Achim Wennmann, The Political Economy of Peacemaking, Routledge, Abingdon, 2011, p. 103.

59 NARCO, Recruiting Ex-offenders: The Employers' Perspective, NARCO, London, 2003. 
the specific work necessary. ${ }^{60}$ In Guatemala the reintegration of former gang members faced significant systematic challenges:

Not only are youth short of the basic abilities required for finding a meaningful job, but they also lack basic inter-personal skills for living in society. Trauma and psychological problems are other impediments. With so much of the population refusing to work with gang members, a major challenge is finding the appropriate sectors of the economy that would be willing to give those gang members who have expressed openness to change an opportunity to reinsert themselves into society. ${ }^{61}$

These attitudes have been mirrored in the business response to employment creation as part of Colombia's demobilization, disarmament, and reintegration (DDR) efforts:

Businesses had apprehensions regarding the conduct of former combatants, who are often seen as pre-disposed to crime, and the combatants' lack of appropriate skills. Concerns were expressed that hiring former combatants will create unease among the firm's existing employees and scare clients away. Others see the possibility of sabotage or retaliation by the armed groups that remain active. ${ }^{62}$

Job creation as a means of AVRP is therefore much clearer in theory than in practice. A recent review on this topic finds that 'the empirical cases for using youth employment programmes as a stand-alone tool for reducing violent conflict are extremely weak. ... The evidence on using job creation as part of an integrated or comprehensive AVRP strategy is much stronger' ${ }^{63}$

\section{The issue of legitimacy and self-interest}

Underlying the multiple roles of business in AVRP programmes is the question as to when a private-sector role becomes a credible contribution to the reduction of armed violence. Such credibility can depend on the legitimacy of business actors in the eyes of a substantive part of the population, its ability to act as a unified actor, and its attitude towards and experience with social engagement. ${ }^{64}$ The credibility of business in AVRP programmes depends on previous behaviour of business in a specific context. For instance, the negative effects of large-scale business investments (for example, mining, dams, agriculture) have led to deep-seated mistrust between the private sector, community groups, and the state in some settings, which in turn

60 L. Capobianco, above note 21, p. 23.

61 Isabel Aguilar Umaña and D. Rossini, Youth Violence in Central America: Lessons from Guatemala, El Salvador and Honduras, Brief No. 4, Geneva Peacebuilding Platform, Geneva, 2012, p. 3.

62 Alexandra Guáqueta, 'Doing business amidst conflict: emerging lessons from Colombia', in J. Banfield et al., above note 18, p. 298.

63 Oliver Walton, Youth, Armed Violence and Job Creation Programmes: A Rapid Mapping Study, Norwegian Peacebuilding Centre, Oslo, 2010.

64 S. Tripathi and C. Gündüz, above note 40, p. 24. 
makes the argument for a constructive role of business in AVRP programmes more difficult.

Another aspect of the credibility of business relates to the level of perceived self-interest of the companies engaging in AVRP. In Colombia, private-sector involvement in peacebuilding was mainly motivated by self-interest. ${ }^{65}$ This argument relates to the common saying that whatever business does, it has to relate to the bottom line. So if AVRP programmes do not show results on the balance sheet, in the end they are unlikely to be of major business interest. However, if AVRP programmes show results they make business sense: fewer operational disruptions, fewer people hurt or killed, and a better international reputation. What is more, if armed violence places key strategic investments at risk, mobilization to combat such violence though direct engagement with perpetrators can be rapid and tremendously pragmatic. In this case, self-interest can be an indicator of real commitment by the company to reduce and prevent armed violence.

\section{Convergence points for cross-sector collaboration}

This section shifts our attention to the strategic potential of the armed violence lens to operationalize cross-sector collaboration in violent contexts. The relationship between business and armed violence is an emerging topic with multiple research and practical opportunities on the ground that builds on a relatively well-developed literature relating business practice to armed conflict, peacebuilding, human rights, and crime prevention. This section highlights three themes where the interests of business, donors, and national stakeholders in a specific context could possibly converge in support of armed violence reduction and prevention. The three themes are the need for cross-sector collaboration, the costs of armed violence, and the development of civic observatories.

\section{Understanding the need for cross-sector collaboration}

Literature on promising practices and anecdotal evidence suggests that the company - as much as government or civil society actors - is not able to reduce violence or prevent armed violence by relying exclusively on its own efforts. The focus is therefore much less on the company's stand-alone contributions to AVRP programmes, but more on how potential corporate contributions can strengthen multi-stakeholder efforts in a specific context. For instance, the Bogota Chamber of Commerce clearly locates its efforts within the broader AVRP strategies and understands its contribution to be in the areas of information generation, objective assessment of security conditions, participation in the formulation of community safety programmes, and development of models strengthening institutional competencies to enable enhancement of community safety. ${ }^{66}$ 
The utility of programming approaches against armed violence is supported by the realization among donors that 'potentially violent tensions or on-going violence are increasingly insusceptible to one-time external mediation or local conflict resolution'. ${ }^{67}$ What is more, the trend has also moved away from implementing blue-print programmes everywhere in the same fashion, because they disregard context-specific issues. ${ }^{68}$

Placing business within broader AVRP programmes also resonates with the trend towards 'constructive accompaniment', which is lending expertise and advice to locally shaped and guided plans and processes. ${ }^{69}$ Constructive accompaniment connects to the local leadership and ownership provisions in the donor guidance, such as the New Deal on Engagement in Fragile States.

Many peacebuilding and development actors perceive the private sector as a positive force in violent and fragile contexts. Investments that facilitate employment growth, skills development, and a more inclusive economy are not only valuable in their own right. As explored in the World Development Report 2011, they also reduce socio-political tensions in ways that help create space for consensus-building on security, civil and economic rights, good government, and other issues critical to stability and development. ${ }^{70}$ The New Deal states that the generation of employment and the improvement of livelihoods is one of five peacebuilding and state-building goals, a stance that opens the door for privatesector actors in a formal peacebuilding and development framework. Drawing on these and other inspirations, the United Nations Secretary-General's 2012 report Peacebuilding in the Aftermath of Conflict calls for 'the private sector and peacebuilding actors to deepen their interaction', and for the engagement with 'foundations and the private sector [to] encourage these actors to contribute to peacebuilding processes'. ${ }^{71}$

Thus there is an increasing expectation that donors and international organizations improve their partnering with the private sector on the ground, and that there is an opportunity for business to better achieve its strategic interest in violence and fragile contexts through cross-sector collaboration. Two concrete points of convergence that could foster such collaboration on armed violence reduction and prevention are related to the costing of armed violence and to the benefit of data-gathering and environment-scanning through observatories.

67 Chetan Kumar and Jos de la Haye, 'Hybrid peacemaking: building national infrastructures for peace', in Global Governance, Vol. 18, No. 1, 2011, p. 13.

68 B. Ganson and A. Wennmann, above note 51, p. 2.

69 Jennifer Milliken, What the Peacebuilding Community Can Contribute to Political Transitions in North Africa and Beyond, Paper 4, Geneva Peacebuilding Platform, Geneva, 2012, p. 12.

70 World Bank, World Development Report 2011: Conflict, Security and Development, World Bank, Washington, DC, 2011.

71 United Nations Secretary-General, Peacebuilding in the Aftermath of Conflict, UN Doc. S/2012/746, 8 October 2012, pp. 5 and 7. 


\section{Costs of armed violence}

Better knowledge on the magnitude and distribution of the costly consequences of armed violence on companies is an important tool to forge business cohesion and convince stakeholders that conflict or criminal violence makes them lose money. Improving costing techniques - such as accounting, modelling, or contingent valuation approaches - would enable better communication of the cost of armed violence to business, especially with regards to the money made or saved through AVRP programmes. ${ }^{72}$

Work on costing could be an important contribution to strengthen efforts by other stakeholders to establish pro-peace or anti-violence constituencies and campaigns. Lining up private sector support behind such efforts is often complicated because companies are not necessarily aware of the magnitude of the cost of armed violence on their operations. While different sectors and companies are affected differently by armed violence - some may even gain from insecurity existing costing methods are not yet fine grained enough to associate costs to specific sectors or companies. ${ }^{73}$ A promising innovation using accounting approaches - a balance sheet of the various cost factors - has been applied to the cost of violence to the health sector. ${ }^{74}$ Sectors particularly sensitive to the effects of armed violence include retail, tourism, financial services, and aviation. ${ }^{75}$

\section{Observatories}

Finding quality data on key risk factors and the gathering of situational intelligence in violent and fragile contexts is as much a challenge for business as it is for development, government, or civil society actors. This is why the model of observatories could be a point of convergence to nurture multi-stakeholder partnerships that strengthen local capacity for data generation and analysis, as well as evidence-based policymaking. Observatories are ad hoc or permanent mechanisms, networks, or institutions that monitor a specific development (for example, violence, disasters, and quality of life). Depending on their mandate, observatories could generate data, provide analysis, and give advice to decisionmakers to strengthen evidence-based policymaking. ${ }^{76}$ They are widely used, especially in Latin America.

72 For a review of costing techniques see GDS, above note 1, pp. 91-97.

73 Ibid.

74 WHO, Manual for Estimating the Economic Costs of Injuries due to Interpersonal and Self-directed Violence, WHO, Geneva, 2008.

75 Global Peace Index, The Study of Industries that Prosper in Peace - the 'Peace Industry', Global Peace Index, Sydney, 2008, pp. 14-18.

76 Elisabeth Gilgen and Lauren Tracey, Contributing Evidence to Programming: Armed Violence Monitoring Systems, GDS, Geneva, 2011. 
For armed violence reduction strategies, observatories are an important force multiplier within a country. Specifically, business could contribute to the following functions of observatories:

- commencing and driving a discussion at the city or national level about the role of data in and monitoring of policymaking,

- pooling professionals in data generation and analysis within a country, and

- organizing a pilot project to generate locally the data necessary to conduct an armed violence baseline analysis or an environment scanning at the subnational level.

In the urban setting of mega-cities, big international companies can also be the main driver of observatories. One of the most ambitious and private-sector-led initiative in this field is the Operations Center in Rio de Janeiro. Designed by IBM at the request of Rio's mayor, the Operations Center is a citywide system that integrates data from some thirty agencies, all under a single roof:

IBM incorporated its hardware, software, analytics and research. It created manuals so that the centre's employees could classify problems into four categories: events, incidents, emergencies and crises. A loud party, for instance, is an event. People beating up each other at a party is an incident. A party that becomes a riot is an emergency. If someone dies in the riot, it's a crisis. The manuals also lay out step-by-step procedures for how departments should handle pressing situations like floods and rockslides. ${ }^{77}$

Overall, observatories could become a convergence point for business, donors, and national stakeholders. Business investment and participation in observatories could be an important connector on AVRP programmes. Observatories address the information, data, and analysis needs of all actors in the context of limited or bad information. What is more, information-gathering and analysis processes are useful themes to initiate a multi-stakeholder process in a specific location.

\section{Conclusion}

This article has provided an exploratory analysis of the armed violence lens in relation to business operations in violent and fragile contexts. On the one hand, the article sought to raise awareness in the business and rights communities about a rapidly evolving field of practice; on the other hand, it aimed to highlight the potential of the armed violence lens to serve as a strategic tool to operationalize cross-sector collaboration in violent and fragile contexts. The article looked at international and local, big and small companies engaged in legal and legitimate business transactions. The article started from the assumption that the new patterns of armed violence observed by a multitude of actors - including the World Bank, the Geneva Declaration, and the OECD - require a new perspective on a subject that has

77 Natasha Singer, 'Mission control, built for cities: IBM takes “smarter cities” concept to Rio de Janeiro', in The New York Times, 3 March 2012. 
traditionally been discussed in the context of 'business and peace' or 'business and conflict' streams of research, which are based on a conceptualization of armed violence related to inter- or intra-state armed conflict.

Overall, understanding the role of business in AVRP programmes is about understanding the role of business practice within violent and fragile contexts as one of many actors that are managing complexity and risk. It is about identifying specific roles for business within larger AVRP programmes, and not about standalone corporate philanthropy. Combatting armed violence is a multi-stakeholder effort and no actor on its own is likely to reduce or prevent armed violence sustainability. This observation connects to a broader trend towards the constructive accompaniment of local efforts, and context-sensitive programme designs.

Businesses have played multiple roles with regard to specific elements of the armed violence lens. For instance, philanthropic investments or capacitybuilding have long been part of company-community relations and fit into the focus on individuals and communities that suffer from or are adversely affected by armed violence. Support given to peace processes or employment creation for excombatants or ex-gang members is an example of ways in which companies directly interact with active or former perpetrators of armed violence.

Ultimately, the armed violence lens may act like a new pair of glasses: it provides a new perspective on existing practice and contributes to making business engagements in violent and fragile contexts more sustainable, while at the same time improving the experience of life of people who are living in these contexts. 